\title{
Heros and Anti-Heros of the Belarusian Independence Project in Chechoslovakia
}

\author{
BY \\ DANIELA KOLENOVSKÁ
}

During the interwar period, two competitive concepts of "Belarusianness" aspired to unite the polity on nationally-imagined ground: the émigré community based its arguments on the unique history, language and culture of Belarus and sought full national independence; (Žuk-Hryškievič 1978, 37-40) the Bolsheviks interpreted nationality as a temporary identity which, if allowed to develop culturally, would fall apart. They believed that a nation, as a form of cultural and economic organisation of a society, would then be replaced by the supranational communist society (Martin 2001, 67-82). To meet this final goal, they introduced korenizatsiya, a programme aiming at the socio-economic development of nonRussians, as part of their ethnic policy. ${ }^{1}$

Czechoslovakia became one of the interwar centres for émigrés from the former Tsarist Russia thanks to the programme known as Russian Aid Operation or Russian Support Action (Ruská pomocná akce). It was announced that the émigrés would be supported both financially and organisationally by the Czechoslovak Ministry of Foreign Affairs in July 1921. As the Czechoslovak leading representatives were convinced that education would facilitate the future return of the refugees to their homeland and help foster its development all-round, stipends for students formed the most important part of the action. Czechoslovak universities accepted those who were able to study in the Czech or Slovak languages and many Russian and Ukrainian educational institutions and cultural associations were founded (Magid 2012, 49-56; Vlček 2012, 19-28; Kopřivová 2018, 290-311).

Russians and Ukrainians dominated among those who found asylum in Czechoslovakia, but Russian Aid Operation was open to other nationals as well. Belarusians formed a less numerous group. Nevertheless, several leading representatives of the Belarusian People's Republic (Bielaruskaja Narodnaja Respublika, henceforth BNR) settled in Czechoslovakia, ensuring Prague had a

1 On the role of the Belarusian version of korenizatsia (BelarusisationBelarusization) within the process of formation of the Belarusian nation, see Marková, A., 2012. Sovětská bělorusizace jako cesta k národu: iluze nebo realita? Praha: Lidové noviny. 2012. 
specific role in the development of Belarusian exiles. However, given international developments, the growing lack of material resources and considerable isolation of Belarusians within the Czechoslovak society, the Czechoslovak part of Belarussian national project gradually fell apart.

While the main strategies, organisations and personalities who took part in this development have already been researched, the breakdown of the Czech-Slovak and Belarusian relationship that caused the fatal lack of Czech or Slovak willingness to protect "their" Belarusians against Soviet despotism after the Second World War requires further analysis. This article addresses this topic by focusing on the activities of the key Belarusian representative of the Protectorate Böhmen und Mähren, Jan Jermačenka. Building on documents stored in contemporary Czech archives, in the State Archive of the Russian Federation (GARF), the Belarusian State Archive-Museum of Literature and Art (BDAMLiM), the Lithuanian Central State Archive (LCVA) and secondary literature, it tries to assess Jermačenka's position in the context of the Belarusian national efforts in Czechoslovakia.

\section{Belarusians in Czechoslovakia}

The Belarusian national programme in the Czechoslovak emigration followed the ideas of the Belarusian movement of the early 20th century. It was strongly stimulated by democratic ideals and the right for self-determination of nations proclaimed at the Paris Peace Conference. Politically, the first Belarusian émigrés in Czechoslovakia were predominantly left-oriented and tended to cooperate with other nations of the former Tsarist Empire on these grounds. The two major Belarusian groups in Czechoslovakia, social revolutionaries and peasants' union members, refused the Soviet model representing the Bolshevik's policy after the late 1920s (Prot'ko 2002, 171-339).

Given the nature of Russian Aid Operation, Belarusian students formed the inevitable basis of any Belarusian organisation in Czechoslovakia. The most important organisation was Belarusian Hramada in Prague (Běloruská hromada v Praze) which was probably founded as a consequence of the Prague All-Belarusian Conference decision to consolidate Czechoslovak-Belarusian relations by opening an office in Prague in September 1921. ${ }^{2}$ In November 1921, Hramada requested its registration as an association for cultural and public enlightenment in support of Belarusians in Czechoslovakia. The unofficial representative of BNR, Mikola

\footnotetext{
2 The All-Belarusian Conference was the only large political event organisedorganized by the BNR Council in Czechoslovakia. It took place at the Municipal House in Prague between September 26 and 28, 1921. Its main objectives were the unification of the fragmented national movement and the Polish-Soviet peace treaty condemnation. In total, 28 delegates and 12 observers met. Minsk, Belaruski dzjaržaŭny (Bielaruski dziaržaŭny archiŭ-muzej litaratury i mastactva, (BDAMLiM), f. 3, op. 1, d. 168, 1. 108, Nagrada 1921.
} 
Viaršynin, was elected its Secretary. On its behalf, he defended the interests of all 49 associated students. Their aims were threefold: firstly, to gain international support for sovereign Belarus, secondly, to raise national language, culture, as well as historical awareness among their countrymen, and thirdly, to morally influence them to prioritise the interests of national sovereignty over the competing political programmes or private interests (Lietuvos centrinis valstybès archyvas (LCVA), f. 582, ap. 2, b. 30, 1-8).

The number of Belarusian émigrés in Czechoslovakia changed throughout the two interwar decades. For these reasons, Belarusian students were able to reach out only exceptionally with their agenda to Czechoslovak society traditionally more receptive to Pan-Slavism. According to official evidence, Belarusians represented less than one percent of the estimated 23 to 25 thousand refugees in Czechoslovakia in 1924. Around one hundred individuals were oriented towards the national priorities (LCVA, f. 366, ap. 1, b. 19, 50-52). Given the changing situation and unclear national identities of the refugees, Tamaš Hryb, the leading Belarusian Socialist-Revolutionary, noted that some three hundred students came to Czechoslovakia from Belarusian guberniyas. Two-thirds of them were described by Hryb as cosmopolitans or former students of Russian universities, the rest of them were described as "Narodniks" - people politically active in the Belarusian exile movement and activities of the BNR.

A research study, initiated by the Czechoslovak Red Cross and carried out at the end of the academic year 1923/1924 across all students of Ukrainian schools in Czechoslovakia, offered a more comprehensive insight into the lives of Belarusian students. It gathered questionnaires from 1824 students, out of which 73 man and 9 women claimed to be Belarusian. Most of the students came to Czechoslovakia from Poland (57). Half of them were over 26 years of age and had graduated from secondary school over seven years before. From the religious point of view, they were a mixed group, wherein Orthodox Christians prevailed. Belarusian students came to Prague mostly as graduates of Belarusian secondary schools (gymnasium) in the cities of Vilnja, Dvinsk and Novogrodek ${ }^{3}$; some had already studied at other universities, and they had not completed their studies because of the war. In Czechoslovakia, they studied in Prague, Poděbrady or Bratislava (Kolenovská and Plavec 2017, 34-40).

The students' poor language skills and low level of integration into the associations of other nations resulted in their relative isolation in Czechoslovak society as well as in the émigré community (Shramchenko and Levko 1927, 249289).

3 Today Vilnius and Daugavpils in Lithuania; Navahrudak in Belarus. 
Czechoslovak authorities were only willing to subsidise Belarusian educational or cultural needs and kept their distance from politics. For Czechoslovakia, it was of vital importance to preserve the Versailles system which the BNR Council, on the contrary, refused to recognise. Both parties thus perceived the stabilisation of the situation in Europe from diametrically opposite views. When the Belarusian officials were forced to leave Lithuania and headed for Czechoslovakia in November 1923, they could do so only as private individuals and could only continue with their activities within the framework of the organisations which were created on the basis of legal provisions for the freedom of association. It was Aliaksandr Ćvikievič who came to Czechoslovakia as the BNR Prime Minister, newly appointed by the President Piotr Krečeŭski (Liachouski 2015, 394-397).

While the main partner of the Czechoslovak authorities was still the moderate Mikola Viaršynin, the arrival of the ambitious Kaunas members of the BNR Council to Czechoslovakia changed the situation between Belarusian émigrés. Paluta Badunova, a member of the presidium of the BNR Council and a Belarusian Socialist-Revolutionary, organised an open protest accusing the "Kaunas group" in Prague of pro-German attitudes and of playing into Polish and communist hands (Lebedeva 2008). She, together with two other influential Belarusian SocialistRevolutionaries, Tamaš Hryb and Jazep Mamońka, tried to open Belarusian Hramada in Prague to Belarusians, which had been so far rejected membership as they had opted for the Union of the Russian Zemstvos and Town Representatives (Ob'jedinennyi komitet Zemskogo soyuza i Soyuza gorodov, Zemgor). However, in January 1924, upon the request of Viaršynin, the Belarusian Hramada ceased to exist and Viaršynin became, for a short time, the President of the newlyregistered Belarusian Council in Prague (Běloruská rada v Praze). Piotr Krečeŭski, Uladzimir Prakulievič and the future BNR Council President, Vasil Zacharka, used the organisation for their own political activities despite the organisation's statutes (Kolenovská and Plavec 2017, 45).

The first success of the Soviet nationalist policy in BSSR and the increased activity of the Soviet secret police among the émigrés contributed to the disputes. In such a situation, the Prime Minister of the BNR Aliaksandr Ćvikievič, and former Minister of Defence of the BNR, Kanstanćin Jezavitaŭ, decided to convene a second All-Belarusian conference in Berlin. Despite the fact that no wider election of the delegates was held, in October 1925, the Belarusian émigrés loyal to Ćvikievič voted for the cessation of the activity of the BNR Council and declared Soviet Minsk the only national centre. The Berlin declaration naturally affected the Belarusians in Czechoslovakia. Officially, they were represented in Berlin by Mikola Viaršynin and Jazep Mamońka, who left the meeting early in protest. Supporters of the Berlin declaration were expelled from the Belarusian Council 
in Prague for committing treason against the national liberation movement. Their conviction that the exiles had to accept their defeat and gather their strength to work in the homeland did not gain the necessary support (Národní archive (NA), f. Policejní ředitelství v Praze, nr. 207, box 400-1).

The Belarusian students' community attempted to secure its interests independently from the "Kaunas group" as well as from those who accepted Soviet Belarus. In August 1924, the majority of Belarusian students, previously united in the Students' Section of Belarusian Hramada, agreed on the wording of the articles of another new organisation: ABSA (Ab'jedinenie Bielaruskich Studentskich Arhanizacij). The organisation aimed at providing a non-political platform for all Belarusian students of Western Belarus and those who had emigrated abroad (LCVA, f. 366, ap. 1, b. 2, 1-5). Thanks to Jan Jermačenka, it succeeded in becoming a free member of the International Student Confederation during its Prague conference in 1926. Hryb was elected to the leadership of ABSA in 1927 as well. He believed all Belarusian students living outside their homeland should unite in ABSA to cooperate with one another and inform international audiences about the fortunes of Belarus (Hardzijenka, eds. 2013, 74-77).

Nevertheless, those who had finished their studies and, as non-citizens, had difficulties finding a job in Czechoslovakia, used the opportunity and left to Poland or Soviet Belarus. The Czechoslovak authorities were increasingly willing to leave the concerns of the Belarusian exiles up to Poland and saw the Belarusian non-communist movement as a part of the political life of Polish minorities. Ignat Dvarčanin took advantage of his contacts with Branislau Taraškievič, moved to Vilnius and became a Deputy of the Polish Parliament. Jan Stankievič made use of the position his brother Adam had among the Belarusians in Vilnius, and partially returned to Poland as well. Adoĺf Klimovič, after obtaining his degree in agronomy in Czechoslovakia in 1928, returned to Vilnius and worked as an official and teacher at the Institute of Economy and Culture in Western Belarus.

Krečeŭski firmly rejected the dissolution of the BNR Council and once again called for the need to join forces in the fight for national liberty. According to Krečeǔski, at that very moment Belarusians had been facing a fundamental decision about whether to give preference to romanticism grounded on the proletarian solidarity and work to develop the national policy solely within the Soviet framework, or whether to strive for Belarusian independence not only at the cultural, but also at the economic and state level. While the first path meant a gradual colonisation, he perceived the second option as an opportunity to fully develop the potential of the Belarusian people (Krečeŭski 1926, 3-6, 146). Tamaš Hryb had his doubts on whether his work for the nation in Czechoslovakia made any sense; however, a departure to Poland, the architect of the Riga Peace Treaty, 
was out of the question for him. So was Soviet Belarus. The Bolsheviks would never agree to even the first point of Hryb's twenty-three claims of 1924 - to abolish the Riga Peace Treaty (Hardzijenka eds. 2013, 380-409). Thus, he kept searching for the positive employment of each emigrant's potential to avert a fatal rift in Czechoslovakia.

In the late-1920s, no scholarships were granted to new students because the budget earmarked for the Russian Aid Operation had been exceeded. Thus, the activities of the Belarusian societies decreased substantially in Czechoslovakia. Still, the Russian Aid Operation met its educational aims even with regard to only insufficiently supported Belarusians. Between 1926 and 1936, 21 doctoral candidates graduated from Charles University. Ten Belarusians doctors who has studied at Charles University became medical practitioners. ${ }^{4}$ Nine Belarusian dissertations were successfully defended at the Faculty of Arts. ${ }^{5}$ Their authors, each of whom was somehow related to Belarusian activities, examined arguments of the national programme in their work.

The first dissertation was defended by Ihnat Dvarčanin, who sought to link the Belarusian programme to the legacy of Francisk Skaryna and his Belarusian translation of the Bible that has been published in Prague in 1517. For Belarusians in Czechoslovak exile, Skaryna represented their traditional connection with Czech high culture, their deep Christianity and long-lived tradition of letterpress printing (Archiv Univerzity Karlovy (AUK), Filozofická fakulta, f. Dizertace I. Dvorčanin sign 1331 (1925/1926)). František Skoryna jako kulturní pracovník a humanista na běloruské půdě). Tamaš Hryb focused on the theoretical anchor of the right of nations and nationalities to self-determination (AUK, Filozofická fakulta, Dizertace I. Dvorčanin sign. 1331 (1925/1926) Otázka národa a národnosti.

Sociologický rozbor národnosti). Mikola Iliaševič described the typical anthropometric and ethnographic features of the Belarusian people and drew a new ethnographical map of Belarus. According to him, Belarusians represented the clearest Slav nation both in terms of anthropometry and culture because of natural conditions (deep forests and swampland). At the same time, he argued that the country's location on the crossroads between East and West formed the Belarusian character as one uniquely open and friendly to foreigners. Thus, Iliaševič believed,

These were: Šyškovský Konstantin, defended (def..) 23. 3. 1928; Lichodzijewska Anna, defended (def.). 28. 6. 1929; Sak Julián, def. 28. 6. 1929; Ermačenko Jan, def. 25. 10. 1929; Zarecki Lejzer, def. 8. 11. 1930; Sadovskaja Marie, def. 20. 12. 1930; Sidoruková Anastazie, def. 14. 3. 1931; Vituško Alexander, def. 21. 12. 1931; Ermačenková Věra, def. 23. 6. 1933; Geniusz Jan, def. 21. 12. 1936. Prague, (Archiv Univerzity Karlovy, fond (AUK), f. Matriky doktorů).

5 These were: Dvorčanin Ignác, abs. 23. 6. 1926; Stankevič Jan, def. 21. 6. 1926; Hryb Tomáš, def. 4. 11. 1927; Iljaševič Mikuláš, def. 12. 10. 1928; Vernikovská Lubov (Ljubor), def. 19. 4. 1929; Czarniecki Mikola (Černecký Mikuláš), def. 7. 6.1929; Slaněvský Ignác, def. 1929/1930, Kraskovskaja Ludmila (Kraskovská)), def. 7. 3. 1931; Hryškevič František, def. 21. 10. 1932. Prague, Archiv Univerzity Karlovy, fond (AUK, f. Matriky doktorů). 
independent Belarus was well-placed to assist with reconciliation within the ethnically and religiously complicated region (AUK, Filozofická fakulta, Dizertace I. Iljaševič sign. 1511 (1927/1928) Bělorus (Bílá Rus) jakožto svérázný celek z antropogeografického hlediska). The opinion that Belarusians are a non-violent and tolerant nation was also supported by the dissertation of Jan Stankievič. He analysed the ancient text al-Kitab, which was written by local Muslims in Belarus from the linguistic point of view (AUK, Filozofická fakulta, Dizertace I. Stankevič sign. 1346 (1925/1926). Náboženská kniha běloruských muslimanů Al-Kitab. Gramatický rozbor řeči po stránce hláskové a tvaroslovné). Another old literary document was studied by Liuboŭ Viernikoŭska. She analysed the Belarusian language elements in the Tale of Igor's Campaign and on these grounds refused any allegations that it was of Belarusian heritage (AUK, Filozofická fakulta, Dizertace I. Vernikovská sign. 1539 (1928/1929) Slovo o pluku Igorově jako umělecká a historická památka).

The idea that Belarusian independence was closely linked to the relation of Poland and Russia was naturally also reflected in the dissertations of the Belarusian students. Whereas Mikola Čarniecki focused on the Polish-Muscovite war of 16321634 (AUK, Filozofická fakulta, Dizertace I. Čarniecký sign 1572 (1928/1929) Válka Polsko-moskevská 1632-1634), Francišak Hryškievič studied the reflections of the Russian thinker Aleksandr Herzen about Slavism in relation to the possible solutions to the problems of Central and Eastern Europe. He believed Herzen found the key in independent Belarus which would restrain the Russian-Polish disputes (AUK, Filozofická fakulta, Dizertace I. Hryškevič sign. 3659 (1932/1933) A. J. Herzen a Slovanstvo).

Liudmila Kraskoŭska was deeply oriented towards science. She obtained her doctorate at Charles University in 1932 for her work on the architecture of the Eastern Slavs, a theme she had already researched at the Mykhail Drahomanov Ukrainian Pedagogical Institute in Prague. Later she founded archeology in Slovakia and became the leading Slovak archeologist (AUK, Filozofická fakulta, Dizertace I. Kraskovskaja (Kraskovská) sign. 1904 (1930/1931), Západní vlivy v architektuře X-XIII. století u východních Slovanů. Slovanská knihovna, speciální sbírky, fond T-DRAH, Inv.č. 41 Personálie - lektoři, zaměstnanci - Kraskovs'ka Ljudmila, listy 41-1-6).

In 1929, the first signs of the world economic crisis had already affected agricultural production. The demand for Czechoslovak industrial goods declined the following year. Widespread support of the educational or cultural activities of the emigrant community was not economically possible any more. Furthermore, Czechoslovak citizens were favoured over émigrés when seeking work or social relief. The peak of the crisis was reached in Czechoslovakia during 1933 and 1934 
(Průcha 2004, 245-404). Simultaneously, Czechoslovakia was flooded by a new wave of refugees. German Jews and German left-oriented politicians brought alarming news about new barbarism, all the more urgent, because it was being perpetuated in direct vicinity and it could easily spread over the borders via the German minority in Czechoslovakia.

In 1934, the year Czechoslovakia recognised the Soviet Union de jure, the Belarusian movement in Czechoslovakia lost its most devoted advocate with the death of Mikola Viaršynin. Tamaš Hryb continued intensely with his exile work and gathered important documents on Belarusian emigration in the Belarusian Foreign Archive. Unfortunately, he died in January 1938, shortly after his 40th birthday (Kolenovská and Plavec 2017, 63). Suddenly, Jermačenka, whose name had been missing for several years from the documents on Belarusian activities in Czechoslovakia, appeared among the members of the committee working on the preparation of the memorial celebration to honour Hryb (Hardzijenka ets. 2017, 453).

\section{Two Faces of One Man: Jermačenka, Ermatchenko}

When compared to the participants of the Ščerbina survey mentioned above, Jermačenka was exceptional. Not only could he speak Czech, Russian, Belarusian, German and a little French, but he was also able to integrate very well. As the former Colonel of the Russian Volunteer Army, he got in touch with Czech authorities as a delegate of the White Russians in Turkey in the summer of 1921(Archiv Kanceláře prezidenta republiky (AKPR), T14/21 (Ruští emigranti), 7). In September 1921, he appeared among the delegates of the Prague All-Belarusian Conference, where he represented Belarusians who at that time found asylum in Turkey and the Kingdom of Serbs, Croats and Slovenes.

On 20 November 1922, he arrived, together with his wife Vera, to Czechoslovakia from Kaunas. He and his wife successfully applied for scholarships from the Czech-Ukrainian committee for the support of Ukrainian and Belarusian students in Czechoslovakia (NA, f. Komitét pro umožnění studia ruským a ukrajinským studentům v ČSR, Jermačenko Jan, 199). They both enrolled at the Faculty of Medicine of Charles University immediately. For Jermačenka, this was an opportunity to start a new career ten years after finishing a Moscow state gymnasium in 1912. He then became a member of the Association of Czech Students of Medicine and of the Union of Russian Students in 1923 (Godarstvennyj arkhiv Rossijskoi Federatsii (GARF), f. 5875, op. 1, d. 6, 11. 42-45).

At that time, Jermačenka shared the opinions of other anti-Soviet Belarusian activists, believing in the need to respect the importance of the political and cultural heterogeneity of national artistic and cultural works. He joined Belarusian 
Hramada in Prague and the Belarusian Peasant Union in Prague. A firm believer in discipline and physical training, he also established contacts with the Czechoslovak Sokol movement. Through Viaršynin, he was able to call for the support of Renáta Tyršová, the daughter of the founder of the Czechoslovak Sokol, Jindřich Fügner, and the wife of his follower Miroslav Tyrš. Thus, in February 1923, when the Czechoslovak authorities refused to make Prague the centre of the international Belarusian Sokol, he worked to mobilise the Belarusian circle within the Czechoslovak Sokol movement. It was the Vinohrady branch of Czechoslovak Sokol which worked to equip the Belarusians with training uniform and Sokol literature and opened its gym to them. The code of rules Jermačenka, together with Belarusian students Todar Klaŭsuć' and Tamaš Vasileŭ, prepared was very demanding.

Jermačenka expected the first fourteen trainees to see not only a personal opportunity in the training but also a moral motivation to be proud of. According to him, the Belarusian Sokol grew as a separatist movement alongside the Russian Sokol and was therefore ready to defend Tyrš's apolitical idea better: "We will serve the entire nation, it is the best goal... the good Sokol does not wait for gratitude... we will be Sokols not only in the gym, but also at home and on the street." He believed the Sokol movement was guaranteed to foster freedom and equality, but, at the same time, he warned his colleagues, that there existed no freedom and equality without law and order. His compatriots, he believed, had come from the fresh air of Belarussian towns and villages to the polluted air in Prague and needed exercise to improve their physical condition after studying. Concurrently, Jermačenka warned those who were coming "only for the muscles and other specific reasons without ideas" that they would quit quickly. The trainings were organised regularly three times a week, starting from 7 o'clock in the morning (Jermačenka 1923, 29-30).

Those who were interested in membership could only apply when they received the support of two guarantors. In the following six-month period, the person applying then had to persuade the other members of her or his suitability and convince them that she or he had the necessary qualities. Beside completing the training, Belarusian Sokols were expected to lecture and publish texts about the Sokol movement, to translate Sokol literature into Belarusian, to organise meetings, celebrations as well as theatre performances, concerts and excursions. In cases of non-appearance at the trainings, a serious explanation was expected. Given the poor condition Belarusians were living in, it was not surprising that the gym became emptier each month (Bielaruski dziaržaŭny archiŭ-muziej litaratury i mastactva (BDAMLiM), f. 3, op. 1, d. 174, 11. 15-26).

Jermačenka himself gave up regular Sokol trainings when he moved to Zbraslav. He joined the Czechoslovak Red Cross there. In 1923, he began to 
travel to Romania to visit his wife's parents and he practiced there as well. In the mid-1920's, he participated in the foundation of ABSA in Prague and represented the organisation before international partners and donors. Upon completing his medical studies, he retreated from any pro-nation activities. In 1929, when Jermačenka graduated, his family found itself facing financial difficulties. In April 1929, his daughter was born and Jermačenka's financial situation forced him to ask the Czech-Ukrainian committee for a loan for necessary expenses. He also applied for an external stipendium from the committee, because he fell ill (suffering from tuberculosis and gastric catarrh) and was not able to find a job. His situation was made more difficult by the fact that, without accepting Czechoslovak citizenship, foreigners could not officially work in his field of expertise.

The Czechoslovak Red Cross supported his requests repeatedly until March 1930 (NA, f. Policejní ředitelství v Praze, Policejní přihlášky, E-67). The very same year, Jan Jermačenka opted to apply for Czechoslovak citizenship. While he had previously sought urgent financial support for his family, he suddenly became a rich private gynecologist. His interests changed. In April 1930, he got his driving license and became member of a motor-touring club in Czechoslovakia. He continued to lecture for the Czechoslovak Red Cross, but he formally left the Sokol movement. The very last activity connecting him to these previous ideals was his attendance of the IX. Sokol Union meeting in Prague in 1931. He served as a member of its Health Department (GARF, f. 5875, op. 1, d. 6, 11. 51-52). Shortly after that, he moved to the centre of Prague and bought a luxurious car. Explaining this to the Czechoslovak authorities, he answered that his family had inherited land in Romania and sold it (Kolenovská and Plavec 2017, 60). After that, Jermačenka was not deeply involved in BNR pro-nation activities for several years.

During 1938, he changed his mind. He started to believe that the Belarusian question would be re-awakened by using the oppportunities given by that historical moment and urged Belarusians in Prague to establish an initiation committee to take advantage of the situation. Under his guidance, they convened a meeting to prepare a precise plan of action on 26 December 1938. During this meeting, financial contributions were collected to support Belarusian activities and Jermačenka announced a programme focused on fostering Belarusian unity and cooperation with the Germans.

When collecting money for Belarusian action, Jermačenka was able to donate 300 crowns, while others could only afford to pay two or ten crowns (GARF, f. 5875, op. 1, d. 27, 1. 70). He used his financial and material resources to quickly gain a respectiful position of authority among Belarusians living in the CzechoSlovak Republic. Thus, a letter pledging the loyalty of Belarusians to Hitler was sent by Jermačenka from Prague to Berlin on 20 April 1939 (BDAMLiM, f. 3, 
op. 1, d. 174). Jermačenka's re-involvement with Belarussian issues culminated with German-Belarusian cooperation in 1941-1943 in the occupied Minsk. However, this also brought about a rapid decay of Czech-Belarusian relations. The anti-Soviet nature of the new Belarusian programme was politically anchored in Germany, the Baltic States and Poland. Politically, the Czechs had preferred Stalin's antifascism to Hitler anticommunism since 1934.

By 1939, Jermačenka was already the father of two daughters, owner of two luxurious cars and a cottage in the countryside and founder of a Belarusian publishing house; he was a successful gynaecologist practising between his surgery in central Prague and the West-Bohemian spa town of Karlovy Vary, where he often flew via Czechoslovak Airlines (NA, f. Policejní ředitelství v Praze, Policejní prrihlášky, E-67). With these resources it was easy for him to win over the control of the Belarusian movement in the Protectorate as well. Believing that Czechoslovakia was a lost project, Jermačenka deepened his argumments in support of the Belarusian pro-German programme by publishing an overview of Belarusian history written by Vasil Rusak and Peter Bakač. It was the first Belarusian publication in Czechoslovakia written in German and signalled the change in his position. According to the map appended by Rusak, the Belarusian territory desired in this plan reached all the way towards the Baltic Sea westwards of Leningrad (Rusak 1939).

With the Molotov-Ribbentrop Pact, the group of supporters of pro-German activities grew and even Janka Stankievič contemplated preparing a programme that would utilise the territorial growth of the Germans and secure at least some more Belarusian territory for the growth of the Belarusian national project from the Soviets (Grzybowski 2011). In this situation, Jermačenka naturally failed in his efforts to gain support for his plans from the top representatives of the Czech political scene. In the beginning of October 1940, Ministers Havelka and Bubna z Litic, as well as President Emil Hácha, turned down his invitation to a concert by Michal Zabejda-Sumicki, a Belarusian tenor. While the Office of the President kept patiently responding to Jermačenka with the explanantion that the President could only accept invitations to very important events for two days, the Ministers merely informed him, via their Secretaries, that they had no interest in the issue and would not attend the concert (AKPR, f. 1286, box 218, S4184/45, D5256, D5241).

Jermačenka and Jan Stankievič also started to publish periodical Belarusian courses in Prague hoping to spread knowledge of Belarusian history and culture by corresponding with Belarusians living in regions controlled by the Germans. This attempt failed in 1941 as there were not many correspondents wealthy enough (GARF, f. 5875, op. 1, d. 30, 29). During 1940 and 1941, Jermačenka managed the branch of the Belarusian Self-Help Committee, the only legal national Belarusian 
organisation, to which every individual of Belarusian origin had to be assigned. As part of this position, he helped register all Belarusians in the Protectorate Böhmen und Mähren in accordance with the Nazi principals of racial categorisation (GARF, f. 5875 , op. 1 , d. 31,40$)$.

Upon the request of Nazi specialist on minorities in the Soviet Union, Gerhardt von Mende from the University of Berlin, Jermačenka used his contacts with former Belarusian students to unite Belarusian doctors prepared to work in Belarusian regions that had fallen under German control as a result of the Molotov-Ribbentrop Pact. Unfortunately, those who did accept his appeals witnessed the horrifying situation in the occupied Belarus (GARF, f. 5875, op. 1, d. 37, 28). A month later, in September 1941, he assisted with Autocephaly Committee for the Belarusian Orthodox Church in Warsaw, which was planned to oppose the influence of the traditional Russian Orthodox Church among the population in Belarus (GARF, f. 5875 , op. 1, d. $37,1.28$ ). By that time, he fully accepted not only the vocabulary of the Nazis but also the idea of the need for Belarusian salvation from the "Bolshevik-Polish-Jewish" exploitation. Finally, in October 1941, Jermačenka was appointed the Head of the Belarusian local administration under the General Commissar Wilhelm Kube in Minsk. Having Kube's approval, he founded the charity Belarusian People's Self-Assistance Committee (Beloruskaya narodnaya samopomoshch), the Belarusian Scientific Society (Bielaruskaje navukovaje tavarystva) and, in July 1942, united Belarusian officers to serve in the interests of Belarusian self-defence (Bielaruski korpus samaabarony). He led all three organisations and, according to documents preserved in Soviet archives, eagerly supported Belarusian émigrés in returning to their homeland and working to build the "New Europe" (GARF, f. 5875, op. 1, d. 37, 11. 1-28).

Jermačenka's programme of Belarusian cultural growth was a language-based plan that excluded any non-Belarusian nationals. The Russians were seen as either "Moscals" who had invaded the territory using temporary German weakness in the 15 th century, or as "Bolsheviks" who had spoiled the Belarusian character with the help of ideology and ordered "partisan bands" to terrorise the peaceful Belarusian nation. According to Jermačenka, the chauvinistic Polish inhabitants of Belarus were not better either. At the same time, anybody educated in former Soviet or Polish schools was suspected of disloyalty to the cause of the Belarusian nation. Jermačenka went so far that he even asked Wilhelm Kube to abolish Polish services in Catholic churches. In his speeches, he blamed both "Moscals" and Poles for letting the Jews settle in the Belarusian territory and control the local administrative apparatus, scientific development and trade (GARF, f. 5875, op. 1, d. 37, 11, 21-24).

The poetess Larysa Hieijuš viewed Jermačenka's sudden rise in importance in national life, especially after Germany's attack on the Soviet Union, negatively. 
Some other Belarusians (especially members of Bielaruskaja Centraĺnaja Rada) acted as Jermačenka, hoping naively that the Soviet Union would disintegrate and an independent Belarusian state under German patronage would be founded. President Zacharka, who influenced the opinions of Hienijuš, was less eager in comparison to Jermačenka. According to her, Belarusians were afraid of Jermačenka not only because he made them agree with political declarations that supported Hitler via fraudulent statements, but also because he was able to endanger their lives and the lives of their relatives working in Reichskommissariat Ostland. Hienijuš believed that Jermačenka collaborated with Germans as well as with the Soviets (Hienijuš 1993).

The hopes of Jermačenka's followers had already proven unfounded during 1943. In March, Vasiĺ Zacharka died. Jermačenka was then dismissed from his posts during his visit in Prague on June 9, 1943. His ambitious plans to increase Belarusian military power were disregarded by the SS leadership. Wilhelm Kube could only save his protégé from being executed. As a result, Belarusian chances to influence from Prague the situation in regions controlled by Germany were marginalised (GARF, f. 5875, op. 1, d. 39, 1. 4).

The reality of this became fully apparent only after 1945. Jermačenka and Stankievič saved their own lives by escaping into American captivity. Jermačenka worked as a doctor for UNRRA in prisoners of war camps in western Germany (Grzybowski 2011, 108). Other Belarusian anti-Soviet activists were not so fortunate and disappeared after being arrested by Soviet authorities in Czechoslovak territory. During 1947 he moved to the United States of America and helped found a new national organisation to support Belarusian emigration to the United States. After the February 1948 communist coup in Czechoslovakia, the Moscow leadership requested the extradition of émigrés who had cooperated with Hitler's Germany. Czechoslovakia agreed to it without closer examination of individual files. Thus, while Larysa and Jan Heniuš were deprived of Czechoslovak citizenship and sent to the Soviet Union, Jermačenka was elected a representative of 48 members of the Bielaruskaja Centraĺnaja Rada in the United States (Hardzijenka 2016, 334, 422-423).

\section{Conclusion}

Jan Jermačenka was able to adapt to different situations in Czechoslovakia. His enormous effort can be seen in all of the most significant actions of the Belarusian community in Czechoslovakia until 1926. He was able to integrate his family very well into Czechoslovak society and became successful in his profession. It is important to note that, despite becoming a Czechoslovak citizen for material 
purposes, Jermačenka stayed loyal to Belarus. As far as the documents and memoirs witness, neither the generous funding of the Russian Aid Operation nor the support of the Czechoslovak Sokol made him feel responsible for the fate of the state which he did not consider his own. Czech authorities eventually lost sympathy for the national programme enforced by the Belarusian-German cooperation after 1939. As a result, Czechoslovakia deprived "its" remaining Belarusians, if they had not left by 1945, of citizenships and turned them over to Moscow after the Second World War.

His sudden wealth played an enormous role in the rise of Jermačenka's influence among emigrants in late 1930s. As international relations developed, the original leaders of the movement lost funding as well as their positions. After Hryb's death, there was no serious opponent strong enough to stand against Jermačenka. Thus, his role in re-shaping the émigré national programme was decisive during the Second World War. He accepted - as he said - Nazi hand and built a plan relying exclusively on extreme Belarusian nationalism. This plan went far behind the limits of the nationally tolerant programme of the original émigré leaders. It threatened the local traditionally heterogeneous population of mixed background and ignored the neighboring nations' interests. As a result, the post-war Sovietisation of Belarus was made easier despite the memory of the Stalinist purges and terror.

The Belarusian collective identity that emerged from cultural trauma caused by the development of Russia in the beginning of the 20th century was defeated by civic nationalism which established a polity recognising the Soviet government, laws and values in Belarus. The original leaders of the Belarusian movement, who had opposed the Soviet régime from exile since the 1920s, were either forgotten or labelled as national traitors. As a result, their ideas lost common ground with the domestic national discourse. Through the Soviet narrative, the pre-war rivalry of the two competing Belarusian projects was solved in favour of the latter, even in Czechoslovakia.

Nevertheless, Jermačenka's path to becoming the anti-hero of the Soviet narrative was not a straightforward one. Neither is the message that his life experience brings for small nations on the Russian western border. While Jermačenka continued to strive for Belarusian independence in the United States of America, Moscow succeeded in discrediting the anti-Soviet Belarusian national programme in Belarus itself and ignored domestic debates on independence until the 1990's. Since then, the inter-war exile's key unresolved question has been revived: Which international and political alliances should Belarus pursue to secure her vital interests? 


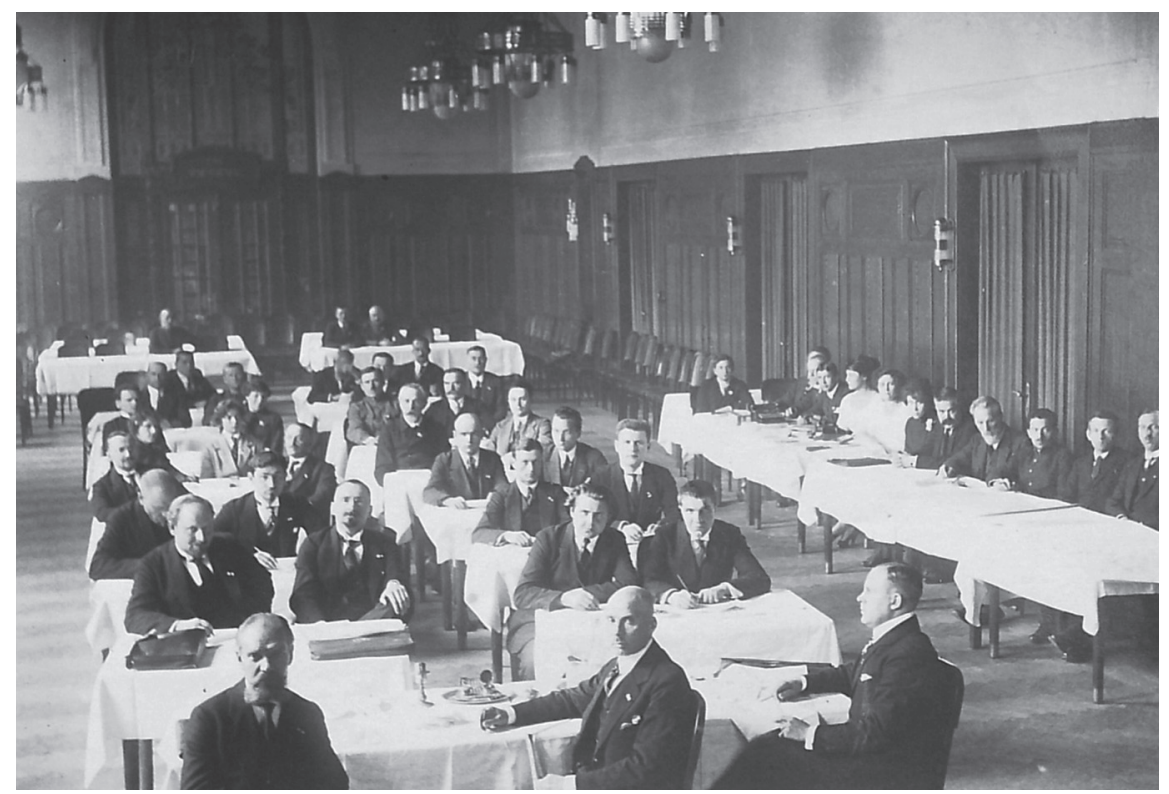

Figure 1: First All-Belarusian Conference in the Municipal House in Prague, September 1921.

Source: Belarusian State Archive-Museum of Literature and Art, collection 3, opis 1 , file 169 , page 108 .

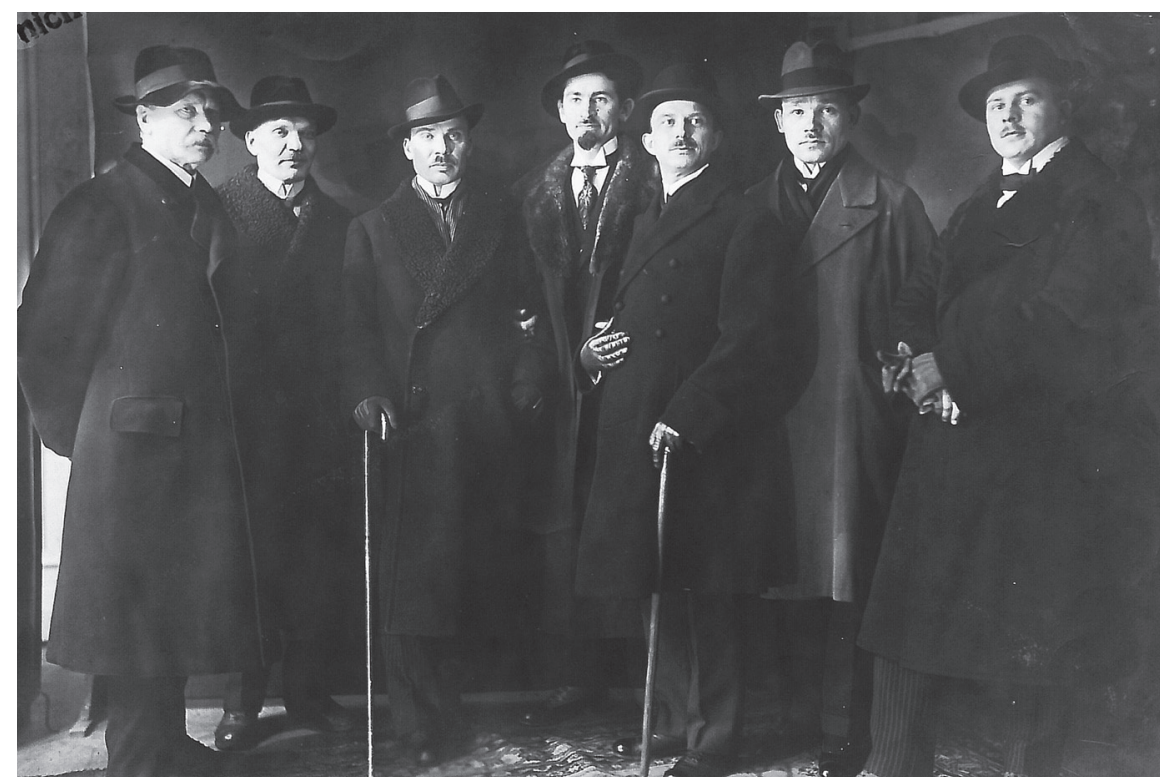

Figure 2: Belarusian activists in Prague, 1918-1919: Ljavon Dubejkovski, Pjotr Krecheuski, Vasil Zakharka, Leanard Zajac, Javhen Ladnov, uknown, Janka Charapuk-Zmahar. (Photograph of Jafim Bjalevič).

Source: Belarusian State Archive-Museum of Literature and Art, collection 3 , opis 3 , file 137 , page 001 . 


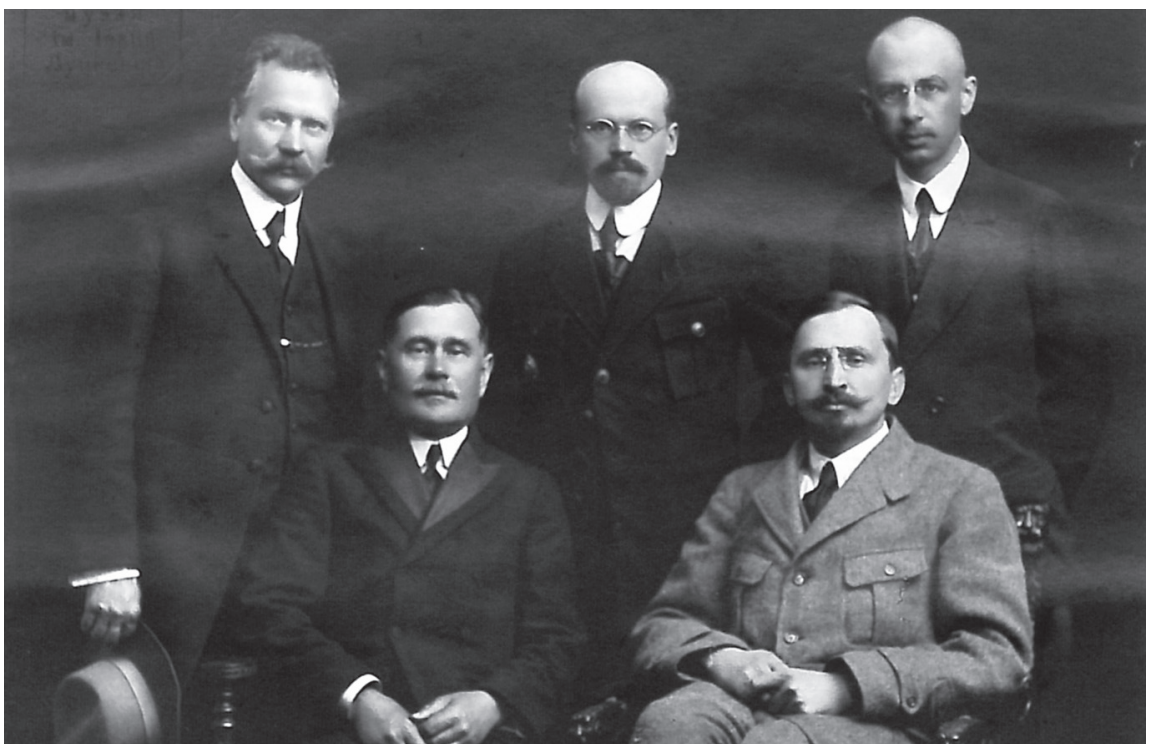

Figure 3: Reprezentatives of Belarusian Gramada in Prague: Mikola Vjarshynin, Aljaksandr Cvikievich; Ljavon Dubejkovski, Aljaksandr Galavinski and Bruno Miller Source: Belarusian State Archive-Museum of Literature and Art, collection 3, opis 3 , file 139 , page 001 .

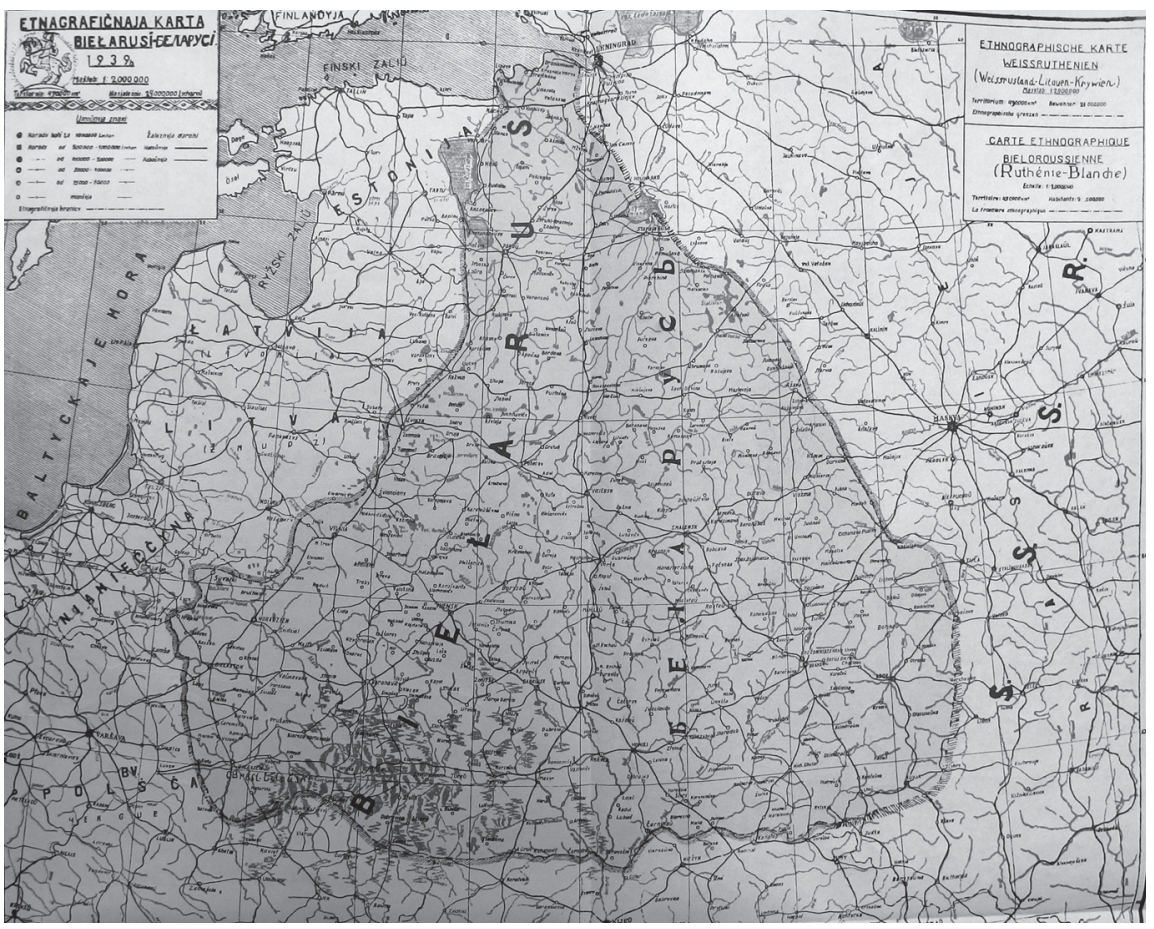

Figure 4: An ethnographic map of teritories claimed for future Belarus by Vasil Rusak in 1939. Source: N. L. Abramchyk ed.: Historyja Biełarusi u kartach: pavodle lekcyj čytanych ing. M. Abramčykam, na kursach biełarusawiedy u Berlinie 1941-42 hodzie. Berlin 1942. 


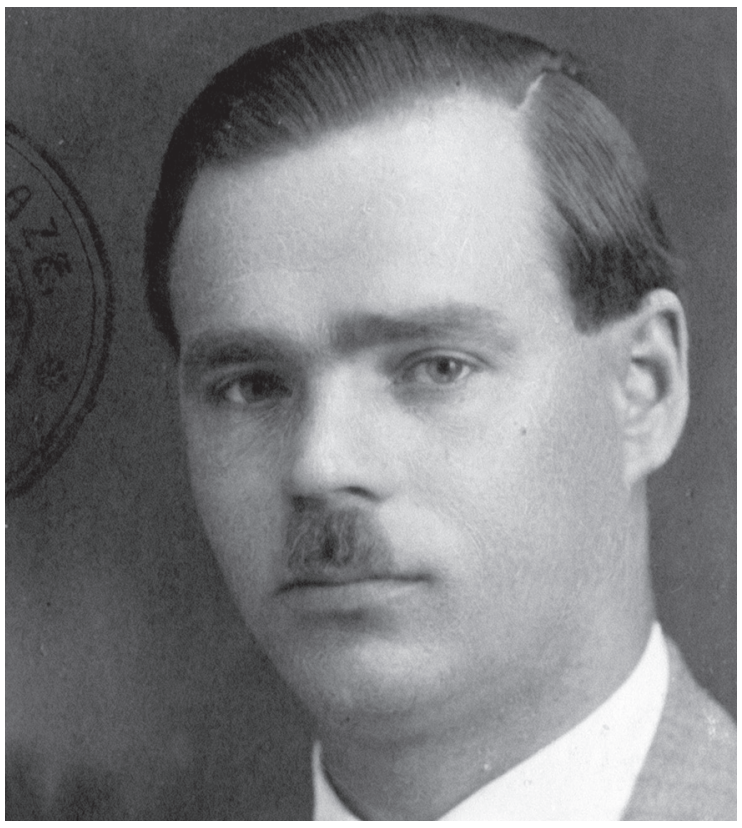

Figure 5:

Jan Jermachenka in 1922.

Source: National Archive of the Czech Republic, collection $1420 / 1 / 3$, box 1952, signature E524/4, page 14 .

Figure 6:

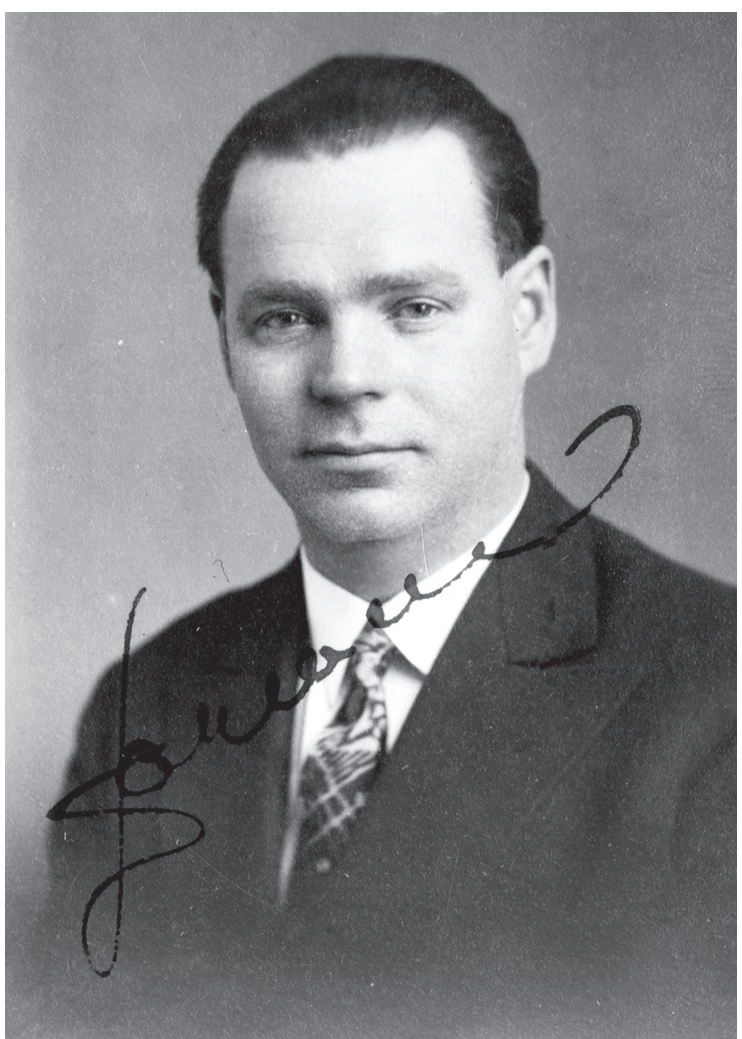

Jan Jermachenka in 1939. Source: National Archive of the Czech Republic, collection $1420 / 1 / 3$, box 1952, signature E524/4, page 9 . 


\section{References}

\section{Archival Collections}

Bielaruski dziaržaŭny archiŭ-muziej litaratury i mastactva (BDAMLiM),

f. 3, op. 1, d. 168, 108 .

f. 3, op. 1, d. 174, 15-26.

Gosudarstvennyj arkhiv Rossijskoi Federacii (GARF),

f. 5875 , op. 1 .

Archiv Kanceláře prezidenta republiky (AKPR),

T14/21 (Ruští emigranti), 7.

f. 1286, box 218, S4184/45, D5256, D5241.

Archiv Univerzity Karlovy (AUK),

f. Matriky doktorů

Filozofická fakulta, f. Dizertace

Národní archive (NA),

f. Policejní ředitelství v Praze, n. 207, box 400-1.

f. Policejní ředitelství v Praze, Policejní přihlášky, E-67.

f. Komitét pro umožnění studia ruským a ukrajinským studentům v ČSR.

Lietuvos centrinis valstybès archyvas (LCVA),

f. 366 , ap. 1, b. $2,1-5$.

f. 366 , ap. 1, b. $19,50-52$.

f. 582 , ap. 2 , b. $30,1-8$.

\section{Secondary Sources}

Abramčyk, N., 1942. Historyja Bielarusi ǔ kartach. Pavodlie liekcyj čytanych ing. M. Abramčykam na kursach Bielarusaviedy ŭ Bierline 1941-1942 hodzie. Prag: Vydannie Bielaruskaha kamitetu samapomačy.

Grzybowski, J., 2011. Pogoń między Ortem Białym, Swastyka i Czerwona Gwiazda : białoruski ruch niepodległościowy w latach 1939-1956. Warszawa: BEL Studio.

Hardzijenka, A., 2016. Bielaruskaja centraĺnaja rada. Stvarennie, dziejnaść, zaniapad. 1943-1995. Minsk: Knigazbor. 
Hardzijenka, N., Jurevič, L., Buča, A. eds., 2013. Rada BNR 1947-1970: padzei, dakumenty, asoby. Mìnsk: Knìhazbor.

Hardzijenka, N., Jurevič, L., Buča, A., eds., 2017. Tamaš Hryb. Vybranae. Minsk: Knigazbor.

Hienijuš, L., 1993. Spoviedź. Minsk: Mastackaja literatura.

Jermačenka, J., 1923. Sakoĺski addziel. Živiem i žyć budzem! Bielaruski student, 7, ss. 29-30.

Kolenovská, D., Plavec, M., 2017. Běloruská emigrace v meziválečném Československu: studie a dokumenty: sociopolitický aspekt. Praha: Univerzita Karlova, Karolinum.

Kopřivová, A., 2018. Výchova a vzdělávání ruské emigrace, in J. Hauser and V. Velemanová, eds., Př́běhy exilu. Osudy exulantů z území bývalého Ruského impéria v meziválečném Československu. Praha: Památník národního písemnictví, ss. 290-311.

Krečeŭski, P., ed., 1926. Zamiežnaja Bielaruś. Zbornik historyi, kultury i ekanomii. Kn. 1. Praha: Vydavnictvo im. F. Skaryny.

Lebedeva, V., 2008. Puciavinami zmagannia i pakutaŭ: Paluta Badunova. Available at: <http://jivebelarus.net/history/faces/paluta-badunova-way-offight-and-sorrow.html $>$ [Accessed 1 October 2018].

Liachouski, U., 2015. Ad homanaŭcaŭ da hajsakoŭ. Smalensk: Inbielkuĺt.

Magid S., 2012., T. G. Masaryk i predistoriya Russkoi aktsii pomoshchi, in L. Babka, I. and Zolotarev, eds., Russkaya aktsiya pomoshchi v Chekhoslovakii. Istoriya, znachenie, nasledie. Praga, Národní knihovna ČR - Ruská tradice, ss. 49-56.

Marková, A., 2012. Sovětská bělorusizace jako cesta k národu: iluze nebo realita? Praha: Lidové noviny.

Martin, T., 2001. An Affirmative Action Empire: The Soviet Union as the Highest Form of Imperialism, in R. G. Suny and T. Martin, eds., A State of Nations. Empire and Nation-Making in the Age of Lenin and Stalin. Oxford-New York: Oxford University Press, pp. 67-90.

Prot'ko, T. S., 2002. Stanovlenie sovetskoy totalitarnoy sistemy v Belarusi. 19171941 gg. Minsk: Tesej.

Rusak, V., 1939. Belarus / Weissruthenien: Kurzer ethnographischer Entwurf übersetzt aus dem weissruthenischen. Prag: Weissruthenischer (krywitschen) Kulturverein Dr. F. Scaryna. 
Shramchenko, L., Ukrains'ke bilorus'ke ta gruzins'ke studenstvo na vysokich školach v Čechoslovac'kij Respublici. (Statističnij naris). in Zapiski Ukrainskoy gospodarskoy akademii v Čechoslovackii Respublici. I. Poděbrady, 1927, ss. 249-289.

Vlček, R., 2012. Sopostavlenie vzglayadov T. G. Masarika i K. Kramarzha. Raznitsa $\mathrm{v}$ ponimanii pomoshchi russkim emigrantam. in L. Babka and I. Zolotarev, eds., Russkaya aktsiya pomoshchi $v$ Chekhoslovakii. Istoriya, znachenie, nasledie. Praga: Národní knihovna ČR - Ruská tradice, ss. 19-28.

Žuk-Hryškievič, V., 1978. 25-ha sakavika: Uspaminy z Miensku, Budslava, Vilini, Prahi, Savieckaj turmy. Toronto: Fond Uspaminaŭ z Bielaruskaha Žyccia. 